\title{
УДОСКОНАЛЕННЯ СИСТЕМИ МОТИВАЦІЇ ПЕРСОНАЛУ ПРОМИСЛОВИХ ПІДПРИЕМСТВ УКРАЇНИ
}

\section{THE IMPROVEMENT OF THE MOTIVATION OF PERSONNEL IN THE INDUSTRIAL ENTERPRISES OF UKRAINE}

\author{
Єпіфранова Ірина Юріївна \\ доктор економічних наук, доцент, \\ Вінницький національний технічний університет \\ ORCID: https://orcid.org/0000-0002-0391-9026 \\ Панкова Валерія Денисівна \\ магістрант, \\ Вінницький національний технічний університет \\ ORCID: https://orcid.org/0000-0002-7491-8880
}

\author{
Yepifanova Iryna, Pankova Valeriia \\ Vinnytsia National Technical University
}

\begin{abstract}
У статті розглянуто теоретичні основи мотивації персоналу, узагальнено існуючі види та методи мотивації. Проаналізовано рух кадрів, структуру витрат на персонал, темпи зростання (зниження) номінальної та реальної заробітної плати на промислових підприємствах України та ефективність мотиваційних заходів. Обґрунтовано важливість нефінансових чинників в процесі мотивації персоналу. Розроблено схему діагностики системи мотивації. Запропоновано впровадження системи преміювання на вітчизняних підприємствах, яка забезпечить покращення продуктивності праці та якості продукції. Удосконалено систему мотивації персоналу шляхом включення обов'язкового впровадження мотиваційного соціального пакета та сучасних інноваційних методів управління, що дозволить підвищити економічну ефективність діяльності підприємства.
\end{abstract}

Ключові слова: персонал, управління персоналом, мотивація, морально-психологічний клімат, людські ресурси.

В статье рассмотрены теоретические основы мотивации персонала, обобщены существующие виды и методы мотивации. Проанализированы движение кадров, структура расходов на персонал, темпы роста (снижения) номинальной и реальной заработной платы на промышленных предприятиях Украины и эффеекивность мотивационных мероприятий. Обоснована важность нефинансовых факторов в процессе мотивации персонала. Разработана схема диагностики системы мотивации. Предложено внедрение системы премирования на отечественных предприятиях, которая обеспечит улучшение производительности труда и качества продукции. Усовершенствована система мотивации персонала путем включения обязательного внедрения мотивационного социального пакета и современных инновационных методов управления, что позволит повысить экономическую эфффективность деятельности предприятия.

Ключевые слова: персонал, управление персоналом, мотивация, морально-психологический климат, человеческие ресурсы.

In modern conditions, human resources are one of the most important elements in the enterprise. For the successful operation of any production and any company, regardless of the services it provides and the goods it produces, you need an efficient work team. The purpose of the article is to determine the directions of the system of motivation of personnel of domestic enterprises. The following general and special methods were used in the research process: abstract-logical and structural-logical analysis - for theoretical generalizations and clarification of the concepts of "personnel management", "personnel evaluation", statistical analysis method for analysis and identification of main trends and management system staff; graphical method - to illustrate the results of the study. The article considers the theoretical foundations of staff motivation, summarizes the existing types and methods of motivation. Motivation is one of the most important elements of the personnel management system, because it is through motivation that the company's management manages to influence employees. Direct economic motivation today is the most important for most Ukrainians, because in an unstable economy, a decent wage is the basis for meeting basic human needs. However, indirect economic and non-economic motivations are also very important and ensure 
employee commitment to the company, increase job satisfaction, reduce staff turnover and, consequently, additional staff costs. The movement of personnel, the structure of personnel costs, growth rates (decrease) of nominal and real wages at industrial enterprises of Ukraine and the effectiveness of motivational measures are analyzed. The importance of non-financial factors in the process of staff motivation is substantiated. The scheme of diagnostics of the motivation system is developed. It is proposed to introduce a system of bonuses at domestic enterprises, which will improve labor productivity and product quality. The system of staff motivation has been improved by including the mandatory introduction of a motivational social package and modern innovative management methods, which will increase the economic efficiency of the enterprise.

Keywords: personnel, personnel management, motivation, moral and psychological climate, human resources.

Постановка проблеми. В сучасних умовах людські ресурси є одним 3 найважливіших елементів в діяльності підприємства. Для успішного функціонування будь-якого виробництва чи суб'єкта господарювання необхідний ефективно працюючий робочий колектив. Для того, щоб підприємство було ефективним, необхідно приділяти значну увагу управлінню персоналом. Нажаль, більшість вітчизняних підприємств недооцінює важливість людських ресурсів і використовує застарілі методи управління персоналом та мотивації, але використання нових підходів може стати вирішальними для підвищення ефективності діяльності підприємства.

Аналіз останніх досліджень та публікацій. Проблемні питання системи управління персоналом та мотивації працівників вивчали різні науковці, зокрема О.В. Довгаль, В.В. Джеджула, Л.І. Заставнюк, Т.Р. Липовецька, А.О. Климчук, А.М. Михайлов та інші. Зокрема, Довгаль О.В. [1] розглядає важливість інноваційного управління персоналом поряд із традиційними, оскільки традиційні методи в сучасних умовах господарювання не завжди $є$ есрективними. В роботі [2] досліджуються особливості формування мотивації працівників промислових підприємств. Войнаренко М.П. та Джеджула В.В. здійснили моделювання процесу мотивації персоналу. Запропонований авторами [3] підхід дозволяє шляхом анонімного анкетування працівників підприємства визначити загальний рівень вмотивованості працюючих і шляхи його покращення в залежності від рівня окремих складових - фрункцій бажаності. В першу чергу зусилля необхідно направляти на реалізацію безвитратних i маловитратних заходів підвищення мотивації і вже після реалізації цих напрямів здійснювати зміни в матеріальному забезпеченні працівників. Климчук А.О., Михайлов А.М. дослідили місце мотивації та стимулювання персоналу в еорективному управлінні підприємством та підвищенні інноваційної діяльності [4].

Виділення невирішених раніше частин загальної проблеми. Разом з тим, потребує подальшого вивчення питання підвищення еорективності діяльності через управління персоналом.

Формулювання цілей статті. Метою статті $€$ визначення напрямів систему мотивації персоналу вітчизняних підприємств.

Виклад основного матеріалу дослідження. Управління персоналом - це стратегічне завдання, яке являє собою розробку кадрової стратегії та просування окремих фрункцій, що знижує витрати на робочу силу, а також створення позитивної соціальної і психологічної атмосорери на робочому місці [1]. Метою управління персоналом є забезпечення підприємства працівниками, які відповідають вимогам певного підприємства, мають здібності до профресійної та соціальної адаптації [2].

Мотивація є одним 3 найважливіших елементів системи управління персоналом, адже саме завдяки мотивації керівництву підприємству вдається здійснювати вплив на працівників. Ефективна мотивація має охоплювати мотиви і стимули. Під мотивом розуміють певну внутрішню потребу, яка спонукає працівника до певних дій і вчинків, внаслідок яких потреба може бути задоволена. Кожна людина має свої мотиваційні преференції, які визначаються її соціальним статусом, добробутом, посадою й іншими чинниками [2].

Виділяють три основних види мотивації, які наведені на рис. 1.

Пряма економічна мотивація на сьогоднішній день є найважливішою для більшості українців, адже в умовах нестабільної економіки гідна заробітна плата $€$ основою для забезпечення базових потреб людини. Однак, непряма економічна та неекономічна мотивація також є дуже важливими і забезпечують прихильність працівників до підприємства, підвищують рівень задоволення роботою, зменшують плинність кадрів і, відповідно, додаткові витрати на персонал.

На рис. 2 зображено графрік витрат на персонал за 2013-2018 роки. Як видно 3 рис. 2, загальні витрати на персонал в 2013-2018 роках значно зросли за рахунок 


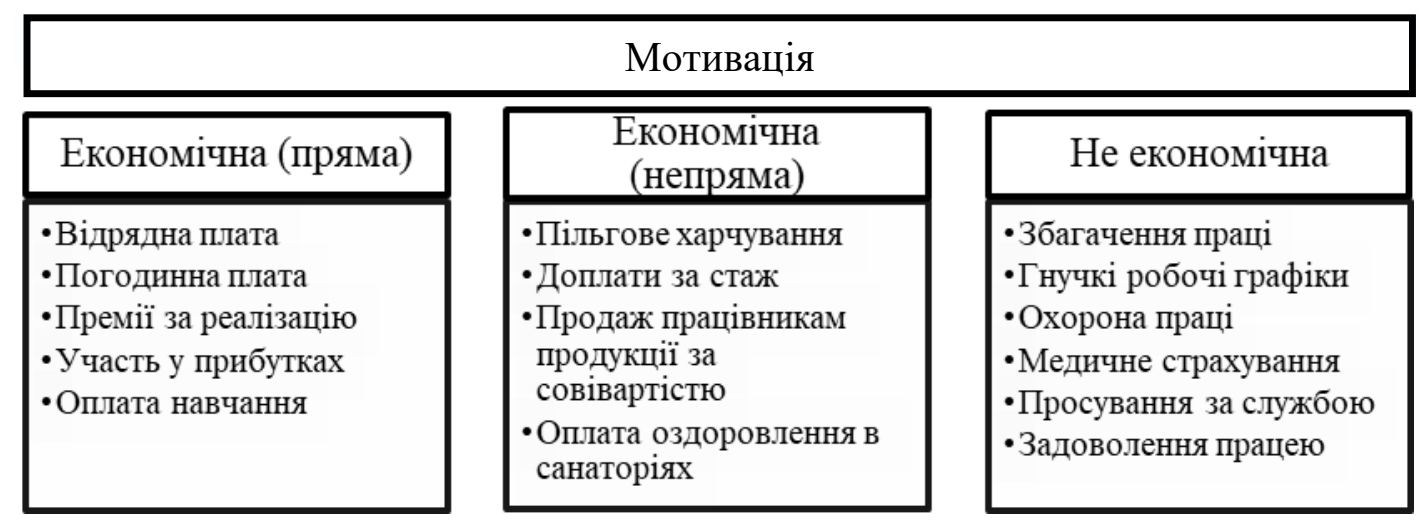

Рис. 1. Види та методи мотивації

Джерело: сформовано автором на основі [4-5]

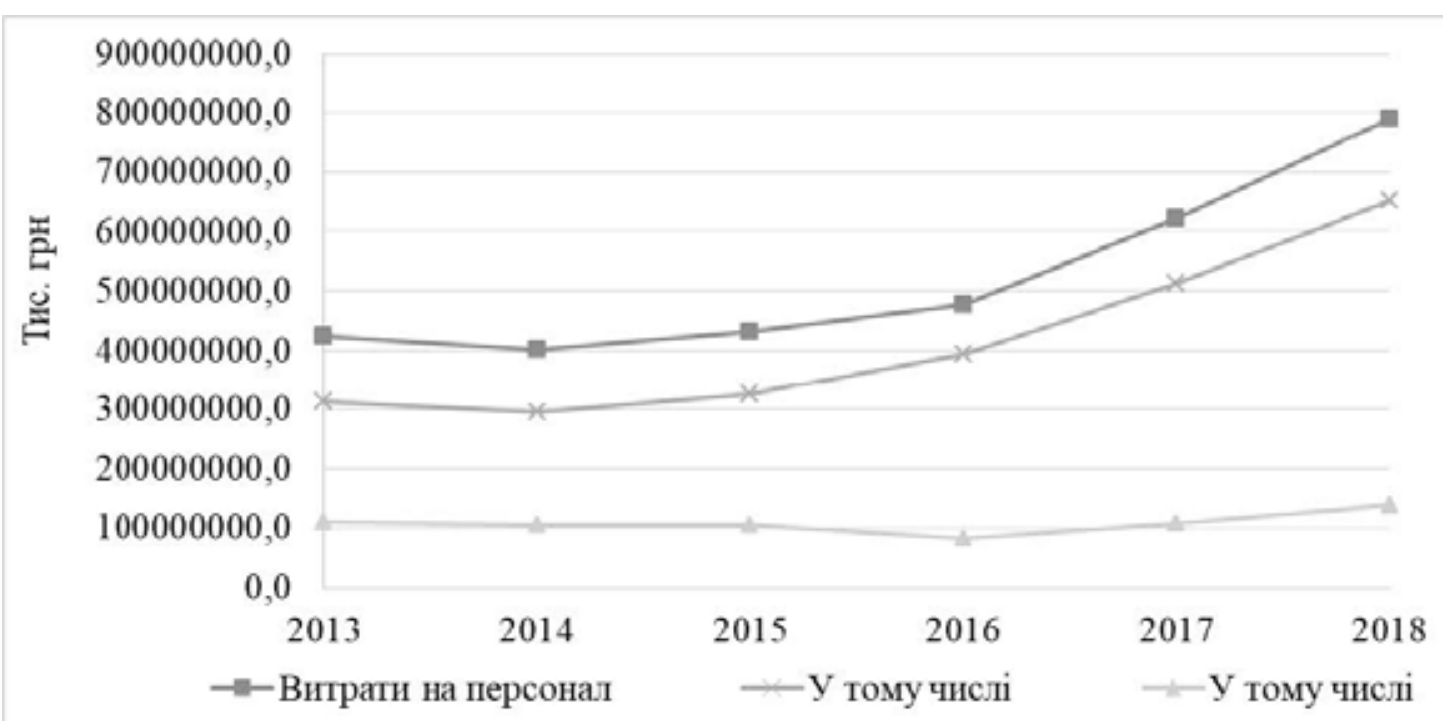

Рис. 2. Структура витрат на персонал підприємствами України

Джерело: складено за [6]

витрат на оплату праці. Відрахування на соціальні заходи фрактично не змінились, що вказує на застосування підприємствами здебільшого економічних фрорм мотивації.

Також це можна підтвердити, поглянувши на середню заробітну плату одного працівника протягом попередніх десяти років в таблиці 1.

Не зважаючи на постійне підвищення заробітної плати та витрат на персонал, реальне збагачення працівників не відбувається у зв'язку зі знеціненням національної валюти. У таблиці 2 зображено темпи зрос- тання (зниження) номінальної та реальної заробітної плати. Як видно 3 таблиці 2, збільшення номінальної заробітної плати не завжди відповідає збільшенню, або навіть супроводжується зниженням реальної заробітної плати. Наприклад, у 2014-2015 роках у зв'язку з кризою та інфрляцією спостерігався значний темп приросту номінальної заробітної плати, при цьому реальна заробітна плата мала негативний темп приросту. Протягом усіх оцінених років темп приросту номінальної заробітної плати перевищує реальну.

Таблиця 1

Середньомісячна заробітна плата штатних працівників у 2010-2019 рр.

\begin{tabular}{|c|c|c|c|c|c|c|c|c|c|c|}
\hline Рік & $\mathbf{2 0 1 0}$ & $\mathbf{2 0 1 1}$ & $\mathbf{2 0 1 2}$ & $\mathbf{2 0 1 3}$ & $\mathbf{2 0 1 4}$ & $\mathbf{2 0 1 5}$ & $\mathbf{2 0 1 6}$ & $\mathbf{2 0 1 7}$ & $\mathbf{2 0 1 8}$ & $\mathbf{2 0 1 9}$ \\
\hline Заробітна плата, грн & 2250 & 2648 & 3041 & 3282 & 3480 & 4195 & 5183 & 7104 & 8865 & 10497 \\
\hline
\end{tabular}


Темпи зростання (зниження) номінальної та реальної заробітної плати за 2010-2019 роки, \%

\begin{tabular}{|c|c|c|}
\hline Рік & $\begin{array}{c}\text { Номінальна } \\
\text { заробітна плата }\end{array}$ & $\begin{array}{c}\text { Реальна } \\
\text { заробітна плата }\end{array}$ \\
\hline 2010 & 117,6 & 110,2 \\
\hline 2011 & 117,7 & 108,7 \\
\hline 2012 & 114,8 & 114,4 \\
\hline 2013 & 107,9 & 108,2 \\
\hline 2014 & 106,0 & 93,5 \\
\hline 2015 & 120,5 & 79,8 \\
\hline 2016 & 123,6 & 109,0 \\
\hline 2017 & 137,1 & 119,1 \\
\hline 2018 & 124,8 & 112,5 \\
\hline 2019 & 118,4 & 109,8 \\
\hline \multicolumn{3}{|c|}{ Джерело: складено за [6] } \\
\hline
\end{tabular}

3 огляду на це можна зробити висновок, що матеріальна мотивація працівників не була ефрективною, адже рівень їхнього життя не покращувався із підвищенням заробітної плати.

На підприємствах України також спостерігається значна плинність кадрів, що відображено в таблиці 3.

Як видно з таблиці 3, потягом останніх трьох років значна кількість звільнень відбувається саме за причини плинності кадрів, а не скорочення штатів. Плинність кадрів - це процес, який відображає зміну працівників підприємства у разі звільнення за власним бажанням або за ініціативою керівництва. Звільнення працівників відбувається, здебільшого, через їхнє незадоволення умовами праці, заробітною платою, політикою компанії, кар'єрним зростанням, атмосфрерою та морально-психологічним кліматом в організації, відсутністю мотивації тощо [7].

Досить важливо звертати увагу на нефінансові чинники, які позитивно впливають на мотивацію. Для ефрективної діяльності колективу є дуже важливим сприятливий морально-

Рух кадрів на підприємствах за 2017-2019 роки

Таблиця 3

\begin{tabular}{|c|c|c|c|c|c|c|}
\hline \multirow{3}{*}{ Рік } & \multirow{3}{*}{$\begin{array}{l}\text { Прийнято, } \\
\text { тис. осіб }\end{array}$} & \multicolumn{3}{|c|}{ Вибуло, тис. осіб } & \multicolumn{2}{|c|}{ \% до попереднього року } \\
\hline & & \multirow[b]{2}{*}{ усього } & \multicolumn{2}{|c|}{ з них із причин } & \multirow[b]{2}{*}{ прийнято } & \multirow[b]{2}{*}{ вибуло } \\
\hline & & & $\begin{array}{c}\text { плинності } \\
\text { кадрів }\end{array}$ & $\begin{array}{c}\text { скорочення } \\
\text { штатів }\end{array}$ & & \\
\hline 2017 & 2341,0 & 2441,1 & 2120,4 & 151,5 & - & - \\
\hline 2018 & 2237,1 & 2420,8 & 2113,4 & 116,4 & 95,6 & 99,2 \\
\hline 2019 & 2100,0 & 2431,0 & 2129,2 & 122,7 & 93,9 & 100,4 \\
\hline
\end{tabular}

Джерело: складено за [6]

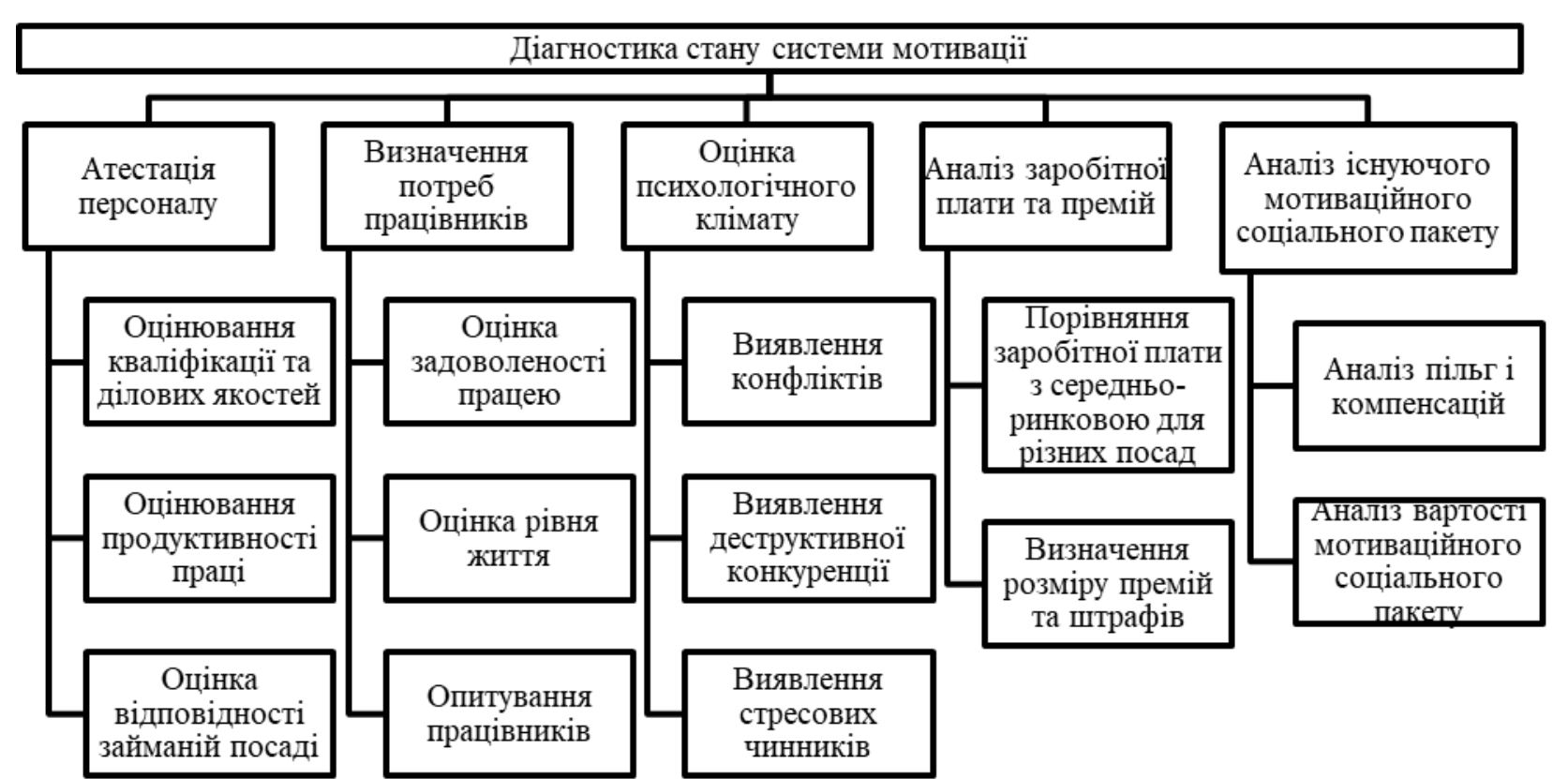

Рис. 3. Діагностика стану існуючої системи мотивації Джерело: сфрормовано автором 


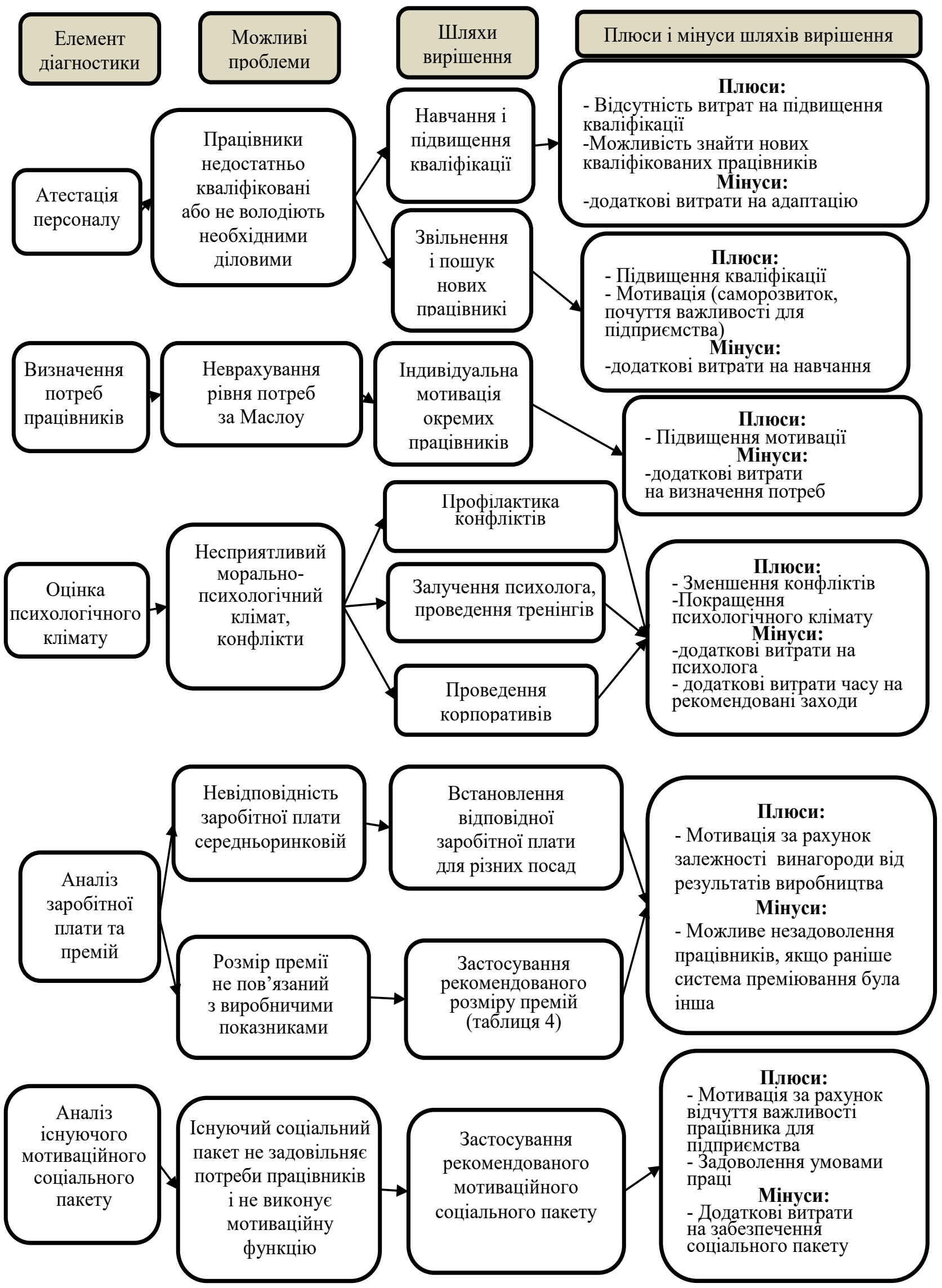

Рис. 4. Удосконалена система мотивації персоналу 
Таблиця 4

Рекомендований розмір премії для мотивації працівників

\begin{tabular}{|l|c|c|c|c|c|}
\hline \multicolumn{1}{|c|}{ Показник преміювання } & \multicolumn{5}{|c|}{ Значенн показника } \\
\hline Рівень виконання плану виробітку, \% & $<90 \%$ & $90-95 \%$ & $95-100 \%$ & $100-105 \%$ & $>105 \%$ \\
\hline $\begin{array}{l}\text { Якість продукції, \% рекламацій } \\
\text { від обсягу виробництва }\end{array}$ & $0,8-1,0 \%$ & $0,7-0,79 \%$ & $0,6-0,69 \%$ & $0,5-0,59 \%$ & $0-0,49 \%$ \\
\hline Розмір премії, \% від окладу & $0 \%$ & $5 \%$ & $10 \%$ & $15 \%$ & $20 \%$ \\
\hline
\end{tabular}

Джерело: сорормовано автором

психологічний клімат. Людина - істота соціальна, тому до діяльності її мотивують не тільки матеріальні, але й моральні стимули. Отже, для промислових підприємств України необхідно покращувати як економічну, так і неекономічну мотивацію.

Для вдосконалення системи мотивації на промислових підприємствах 3 метою підвищення продуктивності праці та мінімізацією витрат необхідно здійснити певну підготовку, продіагностувавши існуючий стан системи за схемою, наведеною на рис. 3.

На рис. 4 зображені шляхи покращення системи мотивації на основі вирішення можливих проблем, виявлених в результаті проведення діагностики стану системи мотивації. Преміювання $€$ важливим елементом економічної мотивації працівників. На промислових підприємствах зазвичай використовується відрядна та відрядно-преміальна фрорми оплати праці, тому доцільно застосовувати систему преміювання за виконанням плану виробництва продукції з урахуванням якості. Якщо показники виконання плану і якості не збігаються, необхідно визначити середнє значення премії. Рекомендований розмір премії наведено в таблиці 4.

Як видно з таблиці 4, за певного рівня виконання плану з обсягу та якості продукції працівники отримуватимуть відповідну премію. Такий підхід буде мотивувати працівників досягати кращих результатів виробництва.

3 метою мотивації доцільно надавати певні пільги своїм працівникам, а саме преміювання, страхування здоров'я за кошти підприємства, пільгове харчування в робочій їдальні, проведення корпоративів та сімейних свят для працівників. Для покращення задоволеності працівників доцільно застосовувати мотиваційний соціальний пакет, до складу якого доцільно включати: надання оплачуваних днів до відпустки, надання гнучкого графріку за проханням працівника, безкоштовний проїзд на роботу, оплата корпоративного мобільного зв'язку, безкоштовне харчування у власній їдальні, медичне страхування, недержавне пенсійне страхування, організація дозвілля.

Висновки. Отже, мотивація $є$ важливим елементом управління персоналом і відіграє значну роль в продуктивності праці і досягнення результатів підприємства. На сьогоднішній день в Україні спостерігається значна плинність кадрів, що вказує на невмотивованість працівників залишатись на робочому місці. Для покращення системи мотивації спершу необхідно продіагностувати існуючу систему та акцентувати увагу на вирішенні існуючих проблем. При застосуванні наведеної системи преміювання можна буде покращувати продуктивність праці та якість продукції. Застосування соціального пакету підсилить прихильність працівників до підприємства і, відповідно, здійснить мотиваційний вплив.

Удосконалено систему покращення мотивації персоналу шляхом передбачення обов'язкового впровадження мотиваційного соціального пакета та сучасних інноваційних методів управління, що дозволить підвищити економічну ефективність діяльності підприємства.

\section{СПИСОК ВИКОРИСТАНИХ ДЖЕРЕЛ:}

1. Довгаль О. В. Інноваційне управління персоналом. Ефективна економіка. 2015 . № 5. URL: http://www.economy.nayka.com.ua/?op=1\&z=4227

2. Єпіфранова І. Ю. Управління інноваційною діяльністю промислових підприємств: теоретико-методологічні аспекти фінансового забезпечення. Вінниця : ВНТУ, 2019. 384 с.

3. Voynarenko M., Dzhedzhula V., Yepifanova I. Modeling of the Process of Personnel Motivation for Innovation Activity. WSEAS Transactions on Business and Economics. 2020. Vol. 17. Pp. 467-477.

4. Джеджула В. В., Єпіфанова І. Ю., Гладка Д. О. Удосконалення кадрової політики як чинник підвищення конкурентоспроможності підприємств. Вісник ОНУ ім. І. І. Мечнікова. 2019. Т. 24. Вип. 2(75). С. 88-92. 
5. Климчук А. О., Михайлов А. М. Мотивація та стимулювання персоналу в ефективному управлінні підприємством та підвищенні інноваційної діяльності. Маркетинг і менеджмент інновацій. 2018. № 1. C. $218-234$.

6. Офріційний сайт Державної служби статистики України. URL: http://ukrstat.gov.ua/

7. Процик І. С., Кара Н. І. Плинність кадрів на підприємстві та шляхи її зменшення. Молодий вчений. 2020. № 3. С. 246-252.

\section{REFERENCES:}

1. Dovhal O. V. (2015) Innovatsiine upravlinnia personalom [Innovative personnel management]. Efektyvna ekonomika, no. 5. Aviable at: http://www.economy.nayka.com.ua/?op=1\&z=4227

2. Yepifanova I. Yu. (2019) Upravlinnia innovatsiinoiu diialnistiu promyslovykh pidpryiemstv: teoretyko-metodolohichni aspekty finansovoho zabezpechennia [Management of innovative activity of industrial enterprises: theoretical and methodological aspects of financial support]. Vinnytsia: VNTU, 384 p. (in Ukrainian)

3. Voynarenko M., Dzhedzhula V., Yepifanova I. (2020) Modeling of the Process of Personnel Motivation for Innovation Activity. WSEAS Transactions on Business and Economics, vol. 17, pp. 467-477.

4. Dzhedzhula V. V., Yepifanova I. Yu., Hladka D. O. (2019) Udoskonalennia kadrovoi polityky yak chynnyk pidvyshchennia konkurentospromozhnosti pidpryiemstv [Improving personnel policy as a factor in increasing the competitiveness of enterprises]. Visnyk ONU im. I. I. Mechnikova, T. 24, no. 2(75), pp. 88-92.

5. Klymchuk A. O., Mykhailov A. M. (2018) Motyvatsiia ta stymuliuvannia personalu v efektyvnomu upravlinni pidpryiemstvom ta pidvyshchenni innovatsiinoi diialnosti [Motivation and stimulation of staff in the effective management of the enterprise and increase innovation]. Marketynh i menedzhment innovatsii, no. 1, pp. $218-234$.

6. Ofitsiinyi sait Derzhavnoi sluzhby statystyky Ukrainy. Aviable at: http://ukrstat.gov.ua/

7. Protsyk I. S., Kara N. I. (2020) Plynnist kadriv na pidpryiemstvi ta shliakhy yii zmenshennia [Staff turnover at the enterprise and ways to reduce it]. Molodyi vchenyi, no. 3, pp. 246-252. 